\title{
KETERBUKAAN EKONOMI DAN PERTUMBUHAN EKONOMI DI LIMA NEGARA ASEAN PERIODE 1996-2017
}

\author{
Nabila Eka Marza Oktavia*, Aris Soelistyo \\ Program Studi Ekonomi Pembangunan, Fkaultas Eknomi dan Bisnis, Universitas Muhammadiyah \\ Malang, Jl.Raya Tlogomas No.246 Malang, Indonesia \\ * Corresponding author: nabilaekamarza0110@gmail.com
}

\begin{tabular}{|c|c|}
\hline Artikel Info & Abstract \\
\hline Article history: & This study aims to determine the effect of foreign debt, \\
\hline Received 6 August 2019 & exports, and inflation on economic growth in the five ASEAN \\
\hline Revised 12 December 2019 & countries in the period 1996-2017. The tool used in this study \\
\hline Accepted 20 January 2020 & is multiple linear regression using panel data by testing \\
\hline Available online 15 February & hypotheses, namely test $f$, $t$ test, coefficient of determination \\
\hline 2020 & $\begin{array}{l}R^{\wedge} 2 \text {. The results of this study show together foreign debt, } \\
\text { exports, and inflation against economic growth in five }\end{array}$ \\
\hline $\begin{array}{l}\text { Keyword: Economic growth; } \\
\text { foreign debt; exports and } \\
\text { inflation }\end{array}$ & $\begin{array}{l}\text { ASEAN countries, with a probability value of } 0.0000 \text {. While } \\
\text { individually foreign debt has a negative and significant effect } \\
\text { on economic growth with a regression coefficient of }-2.599232 \\
\text { and a probability value of } 0.0035 \text {, exports have a positive and }\end{array}$ \\
\hline JEL Classification & significant effect on economic growth with a regression \\
\hline E01, E31, F34 & $\begin{array}{l}\text { coefficient of } 1.801832 \text { and a probability value of } 0.0573 \text {, and } \\
\text { inflation has a negative and significant effect on economic } \\
\text { growth with a regression coefficient of }-0.245798 \text { and a } \\
\text { probability value of } 0.0000 \text {. }\end{array}$ \\
\hline
\end{tabular}

\section{PENDAHULUAN}

Setiap negara mempunyai mimpi besar dalam pertumbuhan ekonomi negaranya. Pembangunan yang dilakukan atau dikerjakan oleh pemerintah dan para ahli ekonomi merupakan cerminan dalam kegiatan kebijakan pembangunan baik masa sekarang maupun masa yang akan datang. Hubungan antar negara dalam faktor ekonomi merupakan hal penting untuk perkembangan masing-masing negara (Purwaning Astuti \& Juniwati Ayuningtyas, 2018). Penilaian keberhasilan dalam kebijakan yang diterapkan dapat mengidentifikasi bahwa perekonomian disetiap daerah sudah merata. Keberhasilan juga dapat dipengaruhi oleh faktor yang ada pada negara itu sendiri yang termasuk didalamnya antara lain sumber daya manusia dan sumber daya modal. Oleh karenanya pertumbuhan ekonomi harus selalu dipelajari, dibenahi jika ada yang kurang, dan dikontrol perkembangannya sehingga didapatkan perekonomian yang tinggi dan lebih baik. Pertumbuhan yang berkelanjutan merupakan suatu keharusan dan utama bagi kondisi keberlangsungan pembangunan ekonomi dan peningkatan kesejahteraan pada suatu negara (Tambunan, 2009).

Dalam pertumbuhan ekonomi peran pemerintah sangatlah penting dikarenakan tugas sebagai pengatur didalam setiap kebijakan yang diterapkan di setiap daerah. Pertumbuhan ekonomi merupakan tujuan dari kebijakan makro, dimana perekonomian yang tumbuh dengan baik mampu memberi kesejahteraan untuk penduduk dinegara yang bersangkutan (Rahmad \& Utomo, 2017). Maka dari itu intervensi tidak lepas dari pengaruh pemerintah, tujuannya sendiri untuk peningkatan ekonomi melalui kebijakan guna mencapai kesejahteraan masyarakat. Tingkat kinerja yang baik dapat 
menunjukkan pertumbuhan ekonomi suatu negara tinggi tiap periodenya, yang tidak hanya melihat jangka pendek akan tetapi juga mendorong pertumbuhan jangka panjang. Pertumbuhan ekonomi adalah indikator dalam menilai perekonomian dalam menganalisis hasil dari pembangunan. Pertumbuhan ekonomi dapat memberi gambaran peningkatan produksi barang dan jasa didalam suatu perekonomian, sehingga pertumbuhan ekonomi menjadi indikator penting dalam suatu analisis pembangunan perekonomian (Nuraini, 2017).

Pembangunan ekonomi yang baik harus dapat bisa dinikmati oleh masyarakat luas. Tidak hanya untuk golongan masyarakat kelas menengah atas akan tetapi juga kalangan masyarakat menengah kebawah. Pada teori pertumbuhan ekonomi yang baru menekankan pada pentingnya peran dari pemerintah terutama peningkatan kualitas sumber daya manusia (SDM), dengan cara meningkatkan keterampilan serta pengetahuan seseorang (Suliswanto, 2017). Dalam percepatan pertumbuhan ekonomi negara sangat memerlukan dana yang cukup besar. Contohnya saja pada faktor produksi yang memerlukan modal untuk membiayai kegiatan perekonomian. Pemenuhan modal ini lah yang menjadi hambatan, sehingga peran pemerintah sangat diperlukan untuk mencari modal yang digunakan sebagai alat kebutuhan pembangunan. Di sisi lain, negara berkembang tidak mempunyai dana yang cukup untuk membiayai kebutuhan pertumbuhan ekonomi negaranya, karena tingkat produktivitas yang masih rendah dan tingginya konsumsi (Yuniasih, 2011).

\section{Gambar 1. Pertumbuhan Ekonomi Lima Negara ASEAN}

Tahun 1996-2017 (\%)

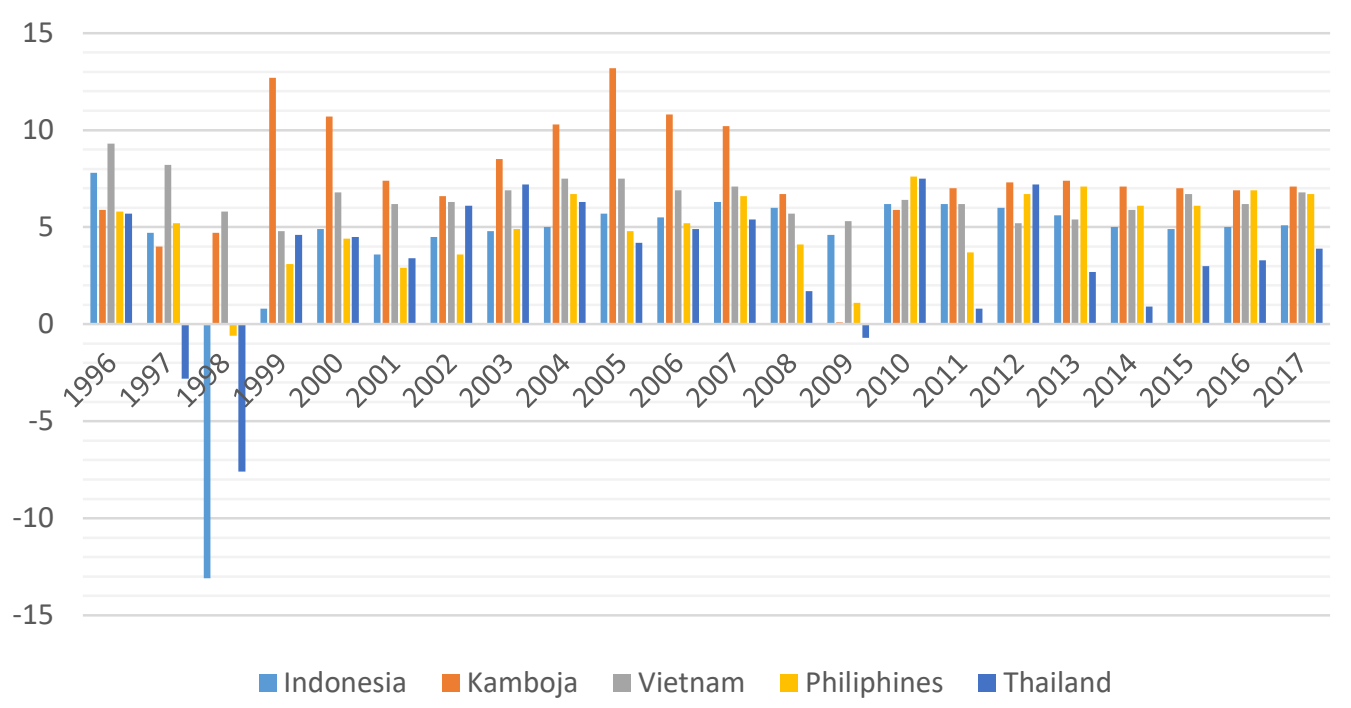

Sumber: data.worldbank.org, 2018 (data diolah)

Gambar 1 dapat dilihat bahwa pertumbuhan ekonomi di kawasan negara berkembang ASEAN yang setiap tahunnya mengalami fluktuasi. Pertumbuhan ekonomi tertinggi terjadi pada negara Kamboja tahun 2005 mencapai angka $13,2 \%$, dan yang mengalami penurunan signifikan terjadi pada negara Indonesia tahun 1998 mencapai angka -13,1\%. Hal ini tidak terlepas dari faktor yang ada pada negara itu sendiri entah itu pada faktor 
alam maupun faktor manusia. Pertumbuhan ekonomi di suatu negara tidak selalu mengalami kenaikan, akan tetapi juga mengalami fluktuasi (Aprillia \& Hariyanti, 2014).

Pembiayaan pembangunan tidak hanya bersumber dari dalam negeri akan tetapi juga dari luar negeri. Utang luar negeri merupakan program pemerintah untuk kepentingan kesejahteraan masyarakat (Sulistyo, 2017). Pencapaian keberhasilan merupakan point penting yang diharapkan oleh setiap negara didalam menjalankan roda perekonomiannya, maka dari itu intervensi yang dilakukan oleh pemerintah sebagai pengontrol roda perekonomian yang ada dimasyarakat agar selalu menutupi defisit anggaran dipemerintahan, pemerintah biasanya menerapkan sistem utang luar negeri. Menurut Todaro (2011:163) dalam Shopia (2018), bantuan yang diberikan dari luar negeri adalah pinjaman dan hibah konfensional resmi, dalam betuk aktiva maupun uang tunai, secara umum digunakan untuk mengalihkan sumber daya dari negara maju ke negara berkembang.

Utang luar negeri bermanfaat sebagai pendanaan modal dalam pembangunan nasional secara berkelanjutan. Misalnya saja utang tersebut digunakan sebagai dana dalam pembelian teknologi modern dan peralatan canggih lainnya yang dapat digunakan sebagai penunjang produksi barang dan jasa, selain itu hutang luar negeri juga dapat digunakan dalam bentuk pembangunan infrastruktur berupa pembangkit listrik, akses jalan, kereta api, pelabuhan, dan lain sebagainya. Dalam tata cara pengelolaan ekonomi global yang terintegrasi, pinjaman atau utang luar negeri adalah suatu hal yang wajar. Yang menjadi masalah adalah bagimana utang tersebut dapat dikelola, digunakan dan dilunasi (Afrianto, 2004: 27 dalam Arfah, 2016).

Utang dapat dikatakan baik jika tidak membebani anggaran dipemerintahan, dengan kata lain rasio yang ada pada hutang tidak melampaui ketentuan yang diterapkan dan pemerintah sendiri dapat mengatur segi pembiayaan utang. Dampak yang akan dirasakan jika negara melakukan pinjaman luar negeri ini ada dua, yang pertama segi negatif jika negara tidak mampu mengelola hutang tersebut sebaik mungkin maka akan membebankan pada generasi yang akan datang dan utang beserta bunga akan terjadi pelonjakan kenaikan yang cukup hebat, yang ke dua segi positif pendapatan dan tabungan negara akan meningkat serta dapat meningkatkan investasi yang akan datang secara terus menerus dikarenakan para investor melihat dengan cara pandang apa yang dimiliki negara tersebut sehingga dapat menguntungkan, yang tidak hanya untung pada investor akan tetapi pada negara yang menerima.

Setelah permintaan dari dalam negeri sudah terpenuhi, satu-satunya cara memperoleh pasar adalah dengan ekspor ke luar negeri (Sukirno, 2011:361 dalam Larasati, 2018). Permintaan merupakan keinginan tiap konsumen untuk suatu barang dengan berbagai macam tingkat harga selama periode tertentu tergantung pada kebutuhan akan barang tersebut (Malik, 2017). Ekspor merupakan faktor penggerak dan pendorong utama bagi negara berkembang (Ginting, 2018). Kegiatan ini merupakan suatu keharusan yang dilakukan negara untuk menunjukkan perdagangan negara dikancah internasional. Ekspor dapat menghasilkan devisa untuk keperluan pembiayaan barang modal serta impor bahan baku yang sangat diperlukan 
dalam proses produksi untuk pembentukan nilai tambah. Perdagangan ekspor adalah mesin bagi negara berkembang untuk pertumbuhan ekonomi. Dalam peningkatan ekspor akan meningkatkan produksi sehingga input tenaga kerja akan meningkat dimana dengan adanya penyerapan tenaga kerja akan menaikkan pendapatan negara (Salvatore 2014: 346 dalam Shopia, 2018).

Ekspor merupakan suatu komoditi yang secara legal diperjual belikan di antar negara. Kebijakan ini sangat diperlukan bagi para pelaku pengusahapengusaha kecil, pengusaha menengah, hingga pengusaha besar. Faktor terpenting menentukan ekspor adalah kemampuan negara tersebut mengeluarkan barang-barang yang akan dapat bersaing didalam pasar luar negeri (Sukirno, 2008: 205 dalam Bonokeling, 2016). Pertumbuhan ekspor dikategorikan terus naik dan meningkat maka dapat menggambarkan perekonomian negara tersebut berjalan dengan baik. Jumlah ekspor dan impor sendiri dapat memberikan gambaran tentang kemampuan negara dalam mengelola serta memproduksi barang dan jasa. Transaksi dalam hal ini meliputi hasil sektor pertanian, barang produksi industri, dan barang yang diproduksi sektor pertambangan dan berbagai jenis barang lainnya (Sukirno, 2011:391 dalam Larasati, 2018).

Pemerintah biasanya memacu pelaku usaha untuk melakukan ekspor. Dengan kata lain pemerintah juga memberi kemudahan dalam segi administrasi, penyediaan komoditas tertentu, hubungan baik antar negara yang melakukan ekspor atau impor, pemerintah juga membantu pengusaha pada sisi promosi barang dagang, pemasaran, pajak yang tidak membebani pelaku usaha sehingga negara dan para pengusaha sama-sama diuntungkan, kegiatan ini tidak akan berhenti begitu saja dengan kata lain kegiatan ekspor antar negara akan terus berlajut untuk periode waktu yang lama. Dengan adanya ekspor yang meningkat dan kapasitas lebih besar dapat meningkatkan produksi sehingga akan memerlukan input berupa tenaga kerja yang berpengaruh pada penyerapan tenaga kerja serta peningkatan pendapatan baik di masyarakat ataupun negara.

Hal lain yang dapat dikategorikan faktor dalam pertumbuhan ekonomi suatu negara adalah inflasi. Inflasi merupakan indikator ekonomi makro yang digunakan untuk mengukur stabilitas ekonomi negara. Inflasi dapat dikatakan sebagai kenaikan tingkat harga yang secara umum dan terus menerus terjadi (Ardiansyah, 2012). Inflasi dapat dikatakan fenomena moneter suatu negara di mana naik turunnya inflasi mengakibatkan gejolak ekonomi. Inflasi tidak biasa dianggap remeh didalam perekonomian, karena jika inflasi bisa diramalkan maka dapat dijadikan acuan dalam pengambilan keputusan kebijakan pemerintah untuk kepentingan aktivitas ekonomi dimasa yang akan datang (Zuhroh, 2008). Jika inflasi melambat juga dapat menjadi masalah pada negara. Inflasi diartikan kenaikan harga yang berlangsung secara terus menerus. Inflasi yang tidak baik atau tidak stabil akan berpengaruh terhadap ketidakpastian para pelaku usaha ekonomi didalam pengambilan keputusan yang akhirnya berdampak pada menurunnya pertumbuhan ekonomi.

Tujuan pemerintah pada tingkat inflasi adalah tetap menjaga agar selalu ditingkat yang rendah, inflasi yang tinggi akan menyebabkan krisis ekonomi diantaranya adalah investasi produktifitas akan berkurang, kegiatan 
perekonomian menurun, produk yang dihasilkan oleh negara tidak dapat bersaing dikanca internasional, penurunan pada ekspor sedangkan impor akan terus meningkat, adanya peningkatan pengangguran, dan neraca pembayaran akan buruk. Menurut Boediono (1999:22) dalam Bonokeling (2016). Negara berkembang umumnya berusaha untuk terus memperbaiki atau menyempurnakan ekonomi internasionalnya

Penelitian yang dilakukan Syaparuddin dkk (2015) mengenai Pengaruh Hutang Luar Negeri Terhadap Pertumbuhan Ekonomi Indonesia, Thailand, Malaysia, Fhilipina, Vietnam dan Burma Periode 1990-2013. Dengan menggunakan pendekatan kuantitatif model analisis data panel menyatakan bahwa hutang luar negeri berpengaruh negatif signifikan terhadap pertumbuhan ekonomi ASEAN.

Penelitian yang dilakukan Shopia dkk (2018) mengenai Pengaruh Foreign Direct Investment, Ekspor, dan Utang Luar Negeri Terhadap Pertumbuhan Ekonomi ASEAN (Studi Pada Produk Domestik Bruto Indonesia, Malaysia, dan Thailand Periode Tahun 2007-2016). Dengan menggunakan pendekatan kuantitatif model analisis data panel menyatakan bahwa FDI, Ekspor berpengaruh signifikan terhadap pertumbuhan ekonomi Indonesia, Malaysia dan Thailand. Utang luar negeri berpengaruh signifikan terhadap pertumbuhan ekonomi Indonesia dan Malaysia, sedangkan berpengaruh tidak signifikan terhadap pertumbuhan ekonomi Thailand.

Penelitian yang dilakukan Larasati dkk (2018) mengenai Pengaruh Inflasi, Ekspor, dan Tenaga Kerja Terhadap Produk Domestik Bruto (PDB) (Studi Pada Indonesia, Malaysia, Singapura, dan Thailand). Dengan menggunakan pendekatan kuantitatif model analisis data panel menyatakan bahwa inflasi berpengaruh negatif dan signifikan terhadap Produk Domestik Bruto (PDB), variabel ekspor berpengaruh positif dan signifikan terhadap Produk Domestik Bruto (PDB), variabel tenaga kerja berpengaruh positif signifikan terhadap Produk Domestik Bruto (PDB).

Penelitian yang dilakukan Al Musadieq dkk (2017) mengenai Pengaruh Ekspor Intra-ASEAN dan FDI Intra-ASEAN Terhadap Pertumbuhan Ekonomi Negara ASEAN (Studi Pada Negara Indonesia, Malaysia, Singapura, Filipina, dan Thailand Tahun 2006-2015). Dengan menggunakan pendekatan kuantitatif model analisis data panel menyatakan bahwa nilai ekspor intra-ASEAN berpengaruh positif signifikan terhadap nilai PDB negara ASEAN, variabel FDI Intra-ASEAN berpengaruh positif signifikan terhadap nilai PDB negara ASEAN.

Perbedaan antara penelitian sebelumnya dengan penelitian ini terletak pada variabel, model, dan sasaran penelitian yang digunakan. Pada penelitian ini menggunakan utang luar negeri, ekspor, inflasi, dan pertumbuhan ekonomi. Model yang digunakan adalah regresi data panel dengan 5 negara yaitu Indonesia, Kamboja, Vietnam, Filipina, dan Thailand dengan tahun observasi 1996 sampai tahun 2017.

\section{METODE PENELITIAN}

Penelitian ini dilakukan di lima negara ASEAN pada tahun 1996-2017. Pemilihan lokasi tersebut dikarenakan faktor negara itu sendiri yang masih dikategorikan kedalam negara berkembang. Jenis penelitian ini deskriptif 
kuantitatif. Teknik yang digunakan adalah randomisasi yaitu pengambilan subyek yang secara acak dari kumpulannya. Teknik sampling merupakan teknik dalam menentukan sampel dengan melihat jumlah dari sampel yang dijadikan sumber data sebenarnya, dengan melihat penyebaran dari populasi sehingga dapat diperoleh hasil representatif. Data yang digunakan adalah data sekunder yang diperoleh dalam bentuk sudah jadi dari worldbank, variabel yang digunakan yaitu variabel bebas utang luar negeri, ekspor, dan inflasi, sedangkan variable terikat adalah pertumbuhan ekonomi.

Data yang digunakan merupakan data panel (pooled data) yaitu cross section dengan time series. Data time series yang digunakan yaitu data tahunan selama 22 tahun dari tahun 1996 hingga 2017, sedangkan data cross section sebanyak 5 negara.

Untuk mengetahui pengaruh dari variabel bebas terhadap variabel terikat dilakukan uji hipotesis Uji-f, Uji-t, dan Koefisien Determinasi $\left(\mathrm{R}^{2}\right)$.

$$
Y=\beta_{0}+\beta_{1} \operatorname{LogX} X_{1}+\beta_{2} \operatorname{LogX} X_{2}+\beta_{3} X_{3}+u \ldots \ldots \ldots \ldots \ldots \ldots \ldots \text { (1) }
$$

Dimana $Y$ adalah Pertumbuhan Ekonomi, $\beta_{0}$ adalah Konstanta, $\beta_{1} \beta_{2} \beta_{3}$ adalah Koefisien Regresi, $\mathrm{X}_{1}$ adalah Variabel Utang Luar Negeri, $\mathrm{X}_{2}$ adalah Variabel Ekspor, $\mathrm{X}_{3}$ adalah Variabel Inflasi, dan $\mathrm{u}$ adalah error term.

Tahap analisis yang dilakukan sebagai berikut: metode estimasi model regresi melalui tiga pendekatan antara lain Metode Pooled Least Square (PLS) atau Commont Effect (CE), Metode Fixed Effect (FE), dan Metode Random Effect (RE). Dalam pemilihan model terbaik estimasi melalui teknik didalam regresi data panel, yaitu tahap Uji Chow dimana untuk menentukan Commont Effect atau Fixed Effect, Uji Lagrange Multiplier (LM) untuk menentukan Random Effect atau Commont Effect, dan Uji Hausman untuk menentukan Fixed Effect atau Random Effect.

\section{HASIL DAN PEMBAHASAN}

ASEAN terdiri dari 10 negara antara lain Indonesia, Brunai Darussalam, Filipina, Kamboja, Laos, Malaysia, Singapura, Myanmar, Thailand, dan Vietnam. Pada penelitian ini yang digunakan hanya 5 negara berkembang yang terpilih yaitu Indonesia, Filipina, Kamboja, Thailand, dan Vietnam.

Analisis data yang dilakukan yaitu Pengaruh Utang Luar Negeri, Ekspor, dan Inflasi Terhadap Pertumbuhan Ekonomi, pemilihan yang dilakukan menggunakan regresi data panel dengan hasil pengujian sebagai berikut:

Pemilihan Model Terbaik

Tabel 1 Hasil Uji Lagrange Multiplier (Breusch-Pagan)

\begin{tabular}{lrrr}
\hline \multicolumn{3}{c}{ Test Hypothesis } \\
\hline & Cross-section & Time & Both \\
Breusch-Pagan & 30.62963 & 9.524506 & 40.15413 \\
& $(0.0000)$ & $(0.0020)$ & $(0.0000)$ \\
\hline
\end{tabular}

Sumber: Data diolah, 2019

Berdasarkan Uji lagrange Multiplier, diperoleh probabilitas dari Breusch Pagan $=0,0000$. Nilai tersebut lebih kecil dari $\alpha(0,05)$, sehingga diputuskan 
untuk menolak $\mathrm{H}_{0}$. Dengan demikian, dapat dikatakan bahwa model Random Effect lebih tepat digunakan dari pada model Common Effect.

Tabel 2 Hasil Uji Chow

\begin{tabular}{lrrr}
\hline Effects Test & Statistic & d.f. & Prob. \\
\hline Cross-section F & 7.888336 & $(4.102)$ & 0.0000 \\
Cross-section Chi-square & 29.648100 & 4 & 0.0000 \\
\hline
\end{tabular}

Sumber: Data diolah, 2019

Berdasarkan Uji Chow, diperoleh Prob. $F=0,0000$. Nilai tersebut lebih kecil dari $\alpha(0,05)$, sehingga diputuskan untuk menolak H0. Dengan Demikian, dapat dikatakan bahwa model Fixed Effect lebih tepat digunakan dari pada model Common Effect.

Tabel 3 Hasil Uji Hausman

\begin{tabular}{lrrr}
\hline Test Summary & Chi-Sq. Statistic & Chi-Sq. d.f. & Prob. \\
\hline Cross-section random & 7.846877 & 3 & 0.0493 \\
\hline Sumber: Data diolah, 2019 & & &
\end{tabular}

Berdasarkan Uji Hausman, diperoleh Prob. $F=0.0493$. Nilai tersebut lebih kecil dari $\alpha(0,05)$, sehingga diputuskan untuk menolak Ho. Dengan demikian, dapat dikatakan bahwa model Fix Effect lebih tepat digunakan dari pada model Random Effect.

Dalam pemilihan model yang dilakukan menggunakan Uji Chow, dan Uji Hausman model yang tepat digunakan yaitu Fixed Effect.

Maka diperoleh regresi sebagai berikut:

Tabel 4 Hasil Estimasi Fixed Effect Model

\begin{tabular}{lcccc}
\hline \multicolumn{1}{c}{ Variable } & Coefficient & Std. Error & t-Statistic & Prob. \\
\hline Utang Luar Negeri & -2.599232 & 0.869313 & -2.989985 & 0.0035 \\
$\quad$ Ekspor & 1.801832 & 0.937191 & 1.922588 & 0.0573 \\
\multicolumn{1}{c}{ Inflasi } & -0.245798 & 0.031648 & -7.766618 & 0.0000 \\
\hline R-squared & 0.514963 & & & \\
Adjusted R-squared & 0.481676 & & & \\
Durbin-Watson stat & 1.723859 & & & \\
F-statistic & 15.47045 & & & \\
Prob(F-statistic) & 0.000000 & & & \\
\hline Sube: Data diol 2019 & & & &
\end{tabular}

Sumber: Data diolah, 2019

\section{Pengujian Hipotesis}

Uji statistik f 
Uji F dilakukan untuk menguji apakah variabel Utang Luar Negeri, Ekspor, dan Inflasi secara simultan berpengaruh terhadap Pertumbuhan Ekonomi dengan ketentuan H0 ditolak bila $\mathrm{f}$ hitung $>\mathrm{f}$ table. Dan $\mathrm{H0}$ diterima bila $\mathrm{f}$ hitung $<\mathrm{f}$ table. Dari tabel 7 diperoleh nilai probabilitas uji $\mathrm{F}$ sebesar 0,0000 dengan F-hitung sebesar 15.47045. Diperoleh F-tabel sebesar 3,081 $\left(\alpha=0,05\right.$ dan $\left.d f_{c}=107\right)$. Sehingga, f-hitung $>$ f-tabel artinya H0 ditolak dan $\mathrm{H} 1$ diterima yang berarti secara bersama-sama Utang Luar Negeri, Ekspor, dan inflasi secara simultan berpengaruh terhadap Pertumbuhan Ekonomi.

\section{Uji Statistik t}

Uji t dilakukan untuk menguji apakah masing-masing variabel Utang Luar Negeri, Ekspor, dan Inflasi secara simultan berpengaruh terhadap Pertumbuhan Ekonomi.

\section{Pengaruh Utang Luar Negeri Terhadap Pertumbuhan Ekonomi}

Berdasarkan hasil penelitian perhitungan statistik uji $t$ dengan model regresi linier berganda data panel dengan model Fixed Effect, diketahui variabel utang luar negeri berpengaruh negatif dan signifikkan terhadap pertumbuhan ekonomi. Apabila hutang luar negeri naik 1\% maka akan menurunkan sebesar $-2.599232 \%$. Hasil tersebut menunjukkan bahwa hutang luar negeri mengalami peningkatan maka akan menurunkan pertumbuhan ekonomi di 5 negara ASEAN. Menjelaskan jika utang luar negeri sebagai defisit anggaran belanja di pemerintah tidak mempengaruhi pertumbuhan ekonomi, karena pengeluaran pemerintah yang dibiayai utang harus dibayar pada masa yang akan datang dengan kenaikan pajak, dan masyarakat akan mengurangi konsumsi masa sekarang untuk memperbesar tabungan periode selanjutnya yang akan digunakan untuk membayar kenaikan pajak yang akan terjadi dimasa akan datang. Hasil penelitian ini didukung oleh Syaparuddin dkk tentang Pengaruh Hutang Luar Negeri Terhadap Pertumbuhan Ekonomi Indonesia, Thailand, Malaysia, Fhilipina, Vietnam dan Burma Periode 19902013.

\section{Pengaruh Ekspor Terhadap Pertumbuhan Ekonomi}

Berdasarkan hasil penelitian dengan model regresi linier berganda data panel dengan model Fixed Effect, variabel ekspor berpengaruh positif dan signifikkan terhadap pertumbuhan ekonomi. Artinya apabila hutang luar negeri naik $1 \%$ maka akan menaikkan pertumbuhan ekonomi sebesar $1.801832 \%$. Hasil tersebut menunjukkan bahwa ekspor mengalami peningkatan maka akan menaikkan pertumbuhan ekonomi di 5 negara ASEAN. Hasil penelitian ini didukung oleh Aya Shopia dkk tentang Pengaruh Foreign Direct Investment, Ekspor, dan Utang Luar Negeri Terhadap Pertumbuhan Ekonomi ASEAN (Studi Pada Produk Domestik Bruto Indonesia, Malaysia, dan Thailand Periode Tahun 2007-2016), dan penelitian Al Musadieq dkk mengenai Pengaruh Ekspor Intra-ASEAN dan FDI IntraASEAN Terhadap Pertumbuhan Ekonomi Negara ASEAN (Studi Pada Negara Indonesia, Malaysia, Singapura, Filipina, dan Thailand Tahun 20062015).

\section{Pengaruh Inflasi Terhadap Pertumbuhan Ekonomi}

Berdasarkan hasil penelitian dengan model regresi linier berganda data panel dengan model Fixed Effect, pengaruh inflasi terhadap pertumbuhan 
ekonomi dari waktu ke waktu adalah negatif sebesar -0.245798 artinya bila ada kenaikan inflasi 1\% maka secara rerata pertumbuhan ekonomi di negaranegara ASEAN yang diteliti meliputi Indonesia, Kamboja, Vietnam, Filipina, dan Thailand akan turun sebesar $-0.245798 \%$. Pertumbuhan ekonomi yang dikaitkan dengan inflasi bermakna bahwa bila inflasi naik maka daya saing produk-produk negara ASEAN di pasar internasional akan menurun kondisi demikian akan menurunkan nilai ekspor, turunnya nilai ekspor akan berdampak pada turunnya gross domestic produk atau pertumbuhan ekonomi yang menurun. Hal ini juga didukung dengan hasil penelitian dimana pengaruh ekspor terhadap pertumbuhan ekonomi positif. Hasil tersebut menunjukkan bahwa inflasi mengalami peningkatan maka akan menurunkan pertumbuhan ekonomi di 5 negara ASEAN. Hasil penelitian ini didukung oleh Larasati dkk tentang Pengaruh Inflasi, Ekspor, dan Tenaga Kerja Terhadap Produk Domestik Bruto (PDB) (Studi Pada Indonesia, Malaysia, Singapura, dan Thailand).

\section{Koefisien Determinasi $\left(\mathbf{R}^{2}\right)$}

Uji determinasi $\mathrm{R}^{2}$ dilakukan untuk mengetahui seberapa besar pengaruh variabel independen terhadap variasi dalam pengaruh dependennya. Hasil analisis regresi data panel dengan model Fixed Effect menunjukkan bahwa koefisien determinasi $\mathrm{R}^{2}$ sebesar 0.51 hal ini menunjukkan bahwa 51\% pertumbuhan ekonomi dipengaruhi oleh variabel hutang luar negeri, ekspor, dan inflasi di 5 negara ASEAN. Sedangkan 49\% sisanya dijelaskan oleh variabel lain diluar model.

Tabel 8 Intersep Model Fixed Effect

\begin{tabular}{clc}
\hline NO & \multicolumn{1}{c}{ CROSSID } & INTERSEP \\
\hline 1. & Negara Indonesia & 1,264189 \\
2. & Negara Kamboja & 0,269088 \\
3. & Negara Vietnam & 1,269781 \\
4. & Negara Filipina & $-0,224678$ \\
5. & Negara Thailand & $-2,578381$ \\
\hline
\end{tabular}

Sumber: Data diolah, 2019

Dengan estimasi sebagai berikut:

Indonesia $=1.264189-2.599232 \mathrm{ULN}+1.801832 \mathrm{EKS}-0.245798 \mathrm{INF}$

Kamboja $=0.269088-2.599232 \mathrm{ULN}+1.801832 \mathrm{EKS}-0.245798 \mathrm{INF}$

Vietnam $=1.269781-2.599232 \mathrm{ULN}+1.801832 \mathrm{EKS}-0.245798 \mathrm{INF}$

Filipina $=-0.224678-2.599232 \mathrm{ULN}+1.801832 \mathrm{EKS}-0.245798 \mathrm{INF}$

Thailand $=-2.578381-2.599232 \mathrm{ULN}+1.801832 \mathrm{EKS}-0.245798 \mathrm{INF}$

Berdasarkan Tabel 8 menunjukkan bahwa hasil intersep dari model Fixed Effect di 5 negara ASEAN memiliki nilai intersep yang berbeda. Bila dilihat dari nilai intersep diatas dapat diketahui bahwa pada negara Vietnam memiliki nilai intersep tertinggi diantara lainnya yaitu sebesar 1.269781, diikuti oleh, Indonesia, Kamboja, Filipina dan terakhir Thailand.

Terlihat Thailand memiliki nilai koefisien terkecil, nilai intersepnya sebesar -2.578381 menjelaskan bahwa jika variabel bebas hutang luar negeri, ekspor, dan inflasi adalah sama dengan nol, maka pertumbuhan ekonomi adalah sebesar $-2.578381 \%$. Nilai koefisien Fixed Effect pada Thailand adalah - 
2.578381 sedangkan nilai $C$ adalah 15.23625 , ini mengartikan bahwa terdapat perubahan pada hutang luar negeri, ekspor, dan inflasi baik antar negara maupun antar waktu, maka Thailand akan mendapatkan pengaruh individu terhadap pertumbuhan ekonomi sebesar $12.657869 \%$. Karena nilai bertanda positif yang berarti akan menambah jumlah pertumbuhan ekonomi.

Vietnam memiliki nilai intersep terbesar yaitu sebesar 1.269781 menjelaskan jika variabel bebas hutang luar negeri, ekspor, da inflasi adalah sama dengan nol, maka pertumbuhan ekonomi Vietnam adalah $1.269781 \%$. Nilai koefisien Fixed Effect pada Vietnam adalah 1.269781 sedangkan nilai C adalah 15.23625, ini mengartikan bahwa terdapat perubahan pada hutang luar negeri, ekspor, dan inflasi baik antar negara maupun antar waktu, maka Indonesia akan mendapatkan pengaruh individu terhadap pertumbuhan ekonomi.

\section{KESIMPULAN DAN SARAN}

Berdasarkan hasil penelitian yang menggunakan data panel regresi linier berganda dengan model Fixed Effect dapat disimpulkan bahwa Utang Luar Negeri, Ekspor, dan Inflasi dengan menggunakan uji f berpengaruh signifikan terhadap Pertumbuhan Ekonomi di 5 negara ASEAN, n nilai F-hitung $15.47045>$ F-tabel 3.081 serta nilai probabilitasnya sebesar 0.0000 . Menggunakan uji secara individu Utang Luar Negeri mempunyai pengaruh negatif dan signifikan, Ekspor mempunyai pengaruh positif signifikan, dan Inflasi mempunyai pengaruh negatif signifikan terhadap Pertumbuhan Ekonomi di Lima negara ASEAN.

Didasarkan pada penelitian yang telah dijelaskan maka saran yang dikemukakan oleh peneliti adalah dengan menjalaskan kebijakan yang dijalankan harus dengan sebaik mungkin agar utang luar negeri tidak salah penempatan yang tidak seharusnya serta tidak menjadi hambatan bagi negara karena utang atau pinjaman luar negeri yang semakin menumpuk, dan tetap menjaga agar inflasi tidak tinggi sebisa mungkin berada pada tingkat rendah, dengan itu pemerintah harus selalu membenahi kebijakan fiskal dengan penghematan belanja pemerintah serta membantu masyarakat terutama para produsen untuk meningkatkan hasil produksi.

\section{DAFTAR PUSTAKA}

Aprillia, \& Hariyanti, D. (2014). Determinasi Pertumbuhan Ekonomi di Negara Asean-6. Media Ekonomi, 22(3), 205. https://doi.org/10.25105/me.v22i3.3192

Ardiansyah, H. (2012). Pengaruh Inflasi Terhadap Pertumbuhan Ekonomi di Indonesia. Jurnal Pendidikan Ekonomi.5(3).

Arfah, W. (2016). Analisis determinan utang luar negeri indonesia (Skripsi). Universitas Islam Negeri Alauddin Makassar, Makassar, Sulawesi Selatan.

Bonokeling, D. E. (2016). Pengaruh Utang Luar Negeri, Tenaga Kerja, dan Ekspor, Terhadap Produk Domestik Bruto di Indonesia Tahun 1986 2015. Revista Brasileira de Ergonomia, 9(2), 10. https://doi.org/10.5151/cidi2017-060 
Fathoni, R. A. R., Al Musadieq, M. \& Supriono. (2017). Pengaruh Ekspor Intra-Asean dan Fdi Intra-Asean Terhadap Pertumbuhan Ekonomi Negara Asean (Studi pada Negara Indonesia, Malaysia, Singapura, Filipina, dan Thailand Tahun 2006-2015). Jurnal Administrasi Bisnis. 45(1). 47-54.

Ginting, A. M. (2018). Analisis Pengaruh Ekspor Terhadap Pertumbuhan Ekonomi Indonesia. Buletin Ilmiah Litbang Perdagangan, 11(1), 1. https://doi.org/10.30908/bilp.v11i1.185

Larasati, I. S., \& Sulasmiyati, S. (2018). Pengaruh Inflasi, Ekspor, dan Tenaga Kerja Terhadap Produk Domestik Bruto (PDB). Jurnal Administrasi Bisnis. 63(1). 8-16.

Nuraini, I. (2017). Kualitas Pertumbuhan Ekonomi Daerah Kabupaten/ Kota di Jawa Timur. Seminar Nasional \& Call For Paper, FEB Unikama "Peningkatan Ketahanan Ekonomi Nasional Dalam Rangka Menghadapi Persaingan Global, 79-93.

Purwaning A. I., \& Juniwati A. F. (2018). Pengaruh Ekspor dan Impor Terhadap Pertumbuhan Ekonomi di Indonesia. Jurnal Ekonomi \& Studi Pembangunan, 19(1). https://doi.org/10.18196/jesp.19.1.3836

Rahmad, B., \& Utomo, Y. P. (2017). Pengaruh Hutang Luar Negeri, Penanaman Modal Asing, dan Tabungan Domestik Terhadap Pertumbuhan Ekonomi Indonesia (1976 - 2000). Jurnal Ekonomi Pembangunan. 6(1). 1225. https://doi.org/10.23917/jep.v6i1.4005

Sandry, H. B., \& Malik, N. (2017). Analisis Harga Internasional, Nilai Tukar, dan Konsumsi Kako Amerika Terhadap Daya Saing ekspor Kakao Indonesia. Jurnal Ilmu Ekonomi. 1(3). 340-351.

Shopia, A., \& Sulasmiyati, S. (2018). Pengaruh Foreign Direct Investment, Ekspor, dan Utang Luar Negeri Terhadap Pertumbuhan Ekonomi Asean (Studi Pada Produk Domestik Bruto Indonesia, Malaysia, dan Thailand Periode Tahun 2007-2016). Jurnal Administrasi Bisnis, 61(3). 20-28.

Sulistyo, A. (2017). Analisis Faktor-faktor yang Mempengaruhi Utang Luar Negeri Indonesia. Jurnal Ekonomi Pembangunan. 1(1). 45-59. https://doi.org/10.1016/j.jff.2015.09.050

Susilowati, D., \& Suliswanto, M. S. W. (2017). Pertumbuhan Ekonomi, Indeks Pembangunan Manusia, Utang Luar Negeri dan Kemiskinan (Kajian Teoritis di Indonesia). Journal of Innovation in Business and Economics, 6(1), 89. https://doi.org/10.22219/jibe.vol6.no1.89-106

Syaparuddin, Umiyati, E., \& Kusuma, J. (2015). Pengaruh Utang Luar Negeri Terhadap Pertumbuhan Indonesia, Thailand, Malaysia, Filipina, Vietnam, dan Burma Periode 1990-2013. Paradigma Ekonomika. 10(01), 7184.

Tambunan, T. (2009). Perekonomian Indonesia. (edisi pert). Bogor: Ghalia Indonesia.

Wahyuningsih, D., \& Zuhroh, I. (2008). Prediksi Inflasi Indonesia. Jurnal Ekonomi Pembangunan. 2(2). 113-127. 
Yuniasih, A. F. (2011). Analisis Pengaruh Foreign Direct Investment ( Fdi ) Terhadap Pertumbuhan Ekonomi Negara Asean Tahun 1980-2009 (Skripsi). Institut Pertanian Bogor, Bogor, Jawa Barat. 